\title{
Pathogen Reduction in Blood Products: What's Behind These Techniques?
}

\author{
Karin Janetzko Peter Bugert \\ Institute of Transfusion Medicine and Immunology, Medical Faculty Mannheim, Heidelberg University; \\ German Red Cross Blood Service Baden-Württemberg - Hessen; Mannheim, Germany
}

The collection, separation and transfusion of red blood cells, platelets, whole plasma and fractionated plasma components are mainstays of our health care system. Each of these elements is essential for the preservation of life and the treatment of disease. With the rise in blood transfusion in the middle of the last century it became clear to the medical community that these life-sustaining and essential therapeutic substances were transmitting life-threatening diseases. Beside immunological risks like febrile and nonfebrile reactions, acute and prolonged hemolytic reactions, transfusion-related acute lung injury (TRALI) or graft-versus-host disease (GvHD) suspicious of transfusion-associated infection raise up first in 1943 when transfusion-associated hepatitis was observed [1]. The introduction of a routine test took about 20 years so that the screening for HBV antigen could be integrated obligatory into the blood donation testing program in 1971. Up to now the implementation of different screening tests, especially NAT testing, for syphilis, HBV, HCV and HIV as well as partly HAV and parvovirus B19minimized the risk of viral transfusion-associated infection considerable. Thus currently the estimated risk for transfusion-associated HBV infection is 1:360,000, for transfusion-associated HCV 1:10.9 million and for transfusion-associated HIV 1:4.3 million [2]. Though the viral problem seems to be managed, one has to take into account that there is still a residual viral transfusion-associated risk due to pathogens for which actually no detection systems exist, e.g. arbovirus, the agent for chikungunya. Moreover, as we learned from the past, viruses still can switch their host in regular periods and move from animal to human pathogenicity such as Ebola (1977), HIV (1981), SARS (2003) or H5N1 virus (2006) [3-5]. It can be assumed that such pathogens can cause fatal diseases due to the transmission via blood. The challenging problem lies in the delayed development of suitable detection systems so that potentially contaminating agents passed undetected into the blood supply. The resulting concerns raised by these events triggered the development of techniques to reduce or even eliminate infectious agents from blood products.

While in the middle of the 1990s the transmission of virus with blood products could be stemmed, the introduction of hemovigilance systems in different countries focused on bacterial transfusion-associated infections, a problem that attracted less attention in the years before. Meanwhile this has become the most frequent infection risk in transfusion medicine and is considered to be associated with a high rate of death from transfusion. Due to the storage condition the highest risk results for platelet products, and a prevalence for bacterial contamination of 1:1,500 per platelet unit was reported [6]. A frequency of 1 in 50,000 platelet transfusions was described for significant clinical events. The mortality rates for platelet-related sepsis range from 1:230,000 to 1:625,000 donor exposures [7, 8]. Based on these findings two major strategies are followed: i) the development of fast screening tests and ii) the development of techniques for inactivation or reduction of these pathogens. Screening tests are based on NAT targeting the uniform bacterial region 16S DNA [9], on FACS technique procedure detecting thiazol orange-stained bacteria [10] or on culturing methods [11]. Pathogen inactivation or reduction techniques came up first in the 1960s, and the methylene blue/light and the solvent-detergent treatment for plasma or plasma components were established. These techniques were not applicable for cellular blood products because cells are sensitive to such chemical or physical treatment. However, at the beginning of the 1990s new promising techniques were developed that use the circumstance that contaminating agents like bacteria, viruses, protozoa and also leukocytes need their DNA or RNA genome for cell function while red blood cell and platelet function is independent from a genome.

\section{KARGER}

Fax +497614520714

Information@Karger.de

www.karger.com (c) 2011 S. Karger GmbH, Freiburg

Accessible online at:

www.karger.com/tmh 
This issue of Transfusion Medicine and Hemotherapy will give an overview on all pathogen reduction techniques which are still used in admitted blood therapeutics or which are actually on their way of development. The review articles written by expert authors summarize comprehensive information on the treatment using riboflavin and UV light [12], amo- tosalen and UVA light [13], S-303 [14], UVC light [15], methylene blue/light [16] and the solvent-detergent technique [17]. Each article is focused on the mechanism of action, toxicity, side effects, clinical efficiency of the treated blood component and the inactivation efficacy on different kinds of pathogens.

\section{References}

1 Beeson PB: Jaundice occurring one to four months after transfusion of blood or plasma. Report of seven cases. JAMA 1943;121:1332-1334.

- 2 Hourfar MK, Jork C, Schottstedt V, Weber-Scheh M, Brixner V, Busch MP, Geusendam G, Gubbe K, Mahnhardt C, Mayr-Wohlfart U, Pichl L, Roth WK, Schmidt M, Seifried E, Wright DJ; German Red Cross NAT Study Group: Experience of German Red Cross blood donor services with nucleic acid testing: results of screening more than 30 million blood donations for human immunodeficiency virus- 1 , hepatitis $\mathrm{C}$ virus, and hepatitis $\mathrm{B}$ virus. Transfusion 2008;48:1558-1566.

3 Woolhouse ME: Population biology of emerging and re-emerging pathogens. Trends Microbiol 2002; 10(suppl):S3-7.

4 Dodd RY, Leibly DA: Emerging infectious threats to the blood supply. Annu Rev Med 2004;55:191207.

5 Barbara J: Why 'safer then ever' may not be quite safe enough. Transfus Med Hemother 2004;349: 1236-1245.

6 Schrezenmeier H, Walther-Wenke G, Müller TH, Weinauer F, Younis A, Holland-Letz T, Geis G, Asmus J, Bauerfeind U, Burkhart J, Deitenbeck R, Förstemann E, Gebauer W, Höchsmann B, Karakassopoulos A, Liebscher UM, Sänger W, Schmidt M, Schunter F, Sireis W, Seifried E: Bacterial contamination of platelet concentrates: results of a prospective multicenter study comparing pooled whole blood-derived platelets and apheresis platelets Transfusion 2007;47:644-652.
7 Perez P, Salmi LR, Follea G, Schmit JL, de Barbeyrac B, Sudre P, Salamon R, BACTHEM group, French Haemovigilance Network: Determinants of transfusion-associated bacterial contamination: Results of the French BACTHEM Case-Control Study. Transfusion 2001;41:862-872

-8 Kuehnert MJ, Roth VR, Haley NR, Gregory KR, Elder KV, Schreiber GB, Arduino MJ, Holt SC, Carson LA, Banerjee SN, Jarvis WR: Transfusion transmitted bacterial infection in the United States, 1998 through 2000. Transfusion 2001;41:1493-1499

9 Schmidt M, Hourfar MK, Nicol SB, Wahl A, Weis C, Tonn T, Sprengler HP, Montag T, Seifried E, Roth WK: A comparison of three rapid bacterial detection methods under simulated real-life conditions. Transfusion 2006;46:1367-1373

10 Dreier J, Vollmer T, Kleesiek K: Novel flow cytometry-based screening for bacterial contamination of donor platelet preparations compared with other rapid screening methods. Clin Chem 2009;55:14921502

11 Walter-Wenke G, Schrezenmeier H, Deitenbeck R, Geis G, Burkhart J, Höchsmann B, Sireis W, Schmidt M, Seifried E, Gebauer W, Liebscher UM, Weinauer F, Müller TH: Screening of platelet concentrates for bacterial contamination: spectrum of bacterial detection, proportion of transfused units, and clinical follow up. Ann Hematol 2009; DOI: $\underline{10.1007 / \mathrm{s} 00277-009-0762-2}$
12 Marschner S, Goodrich RP: Pathogen reduction technology treatment of platelets, plasma and whole blood using riboflavin and UV light. Transfus Med Hemother 2011;38(1):8-18.

13 Irsch J, Lin L: Pathogen inactivation of platelet and plasma blood components for transfusion using the INTERCEPT blood system. Transfus Med Hemother 2011;38(1):19-31.

14 Henschler R, Seifried E, Mufti N: Development of the S-303 pathogen inactivation technology for red blood cell concentrates. Transfus Med Hemother 2011;38(1):33-42.

15 Seltsam A, Müller TH: UVC irradiation for pathogen reduction of platelet concentrates and plasma. Transfus Med Hemother 2011;38(1):43-54.

16 Seghatchian J, Struff WG, Reichenberg S: Main properties of the THERAFLEX MB-plasma system for pathogen reduction. Transfus Med Hemother 2011;38(1):55-64.

17 Hellstern P, Solheim BG: The use of solvent/detergent treatment in pathogen reduction of plasma. Transfus Med Hemother 2011;38(1):65-70. 